\title{
The influence factors of enterprise group internal capital market excess value empirical research
}

\author{
Xu an Gong Zhi-wen \\ School of Management and Economics, Jingdezhen Ceramic Institute,Jingdezhen 333001, China
}

Key words: is a family enterprise group, the internal capital market, the excess value

\begin{abstract}
: the article on the business group internal capital market, on the basis of capital allocation excess value measure, is a family enterprise as samples, empirically the influence factors of enterprise group internal capital market excess value. Study shows that the system the excess value of group, the generally low, and is the first big shareholder's stake related to the separation and cash flow rights and control difference degree negative correlation, and tests by $5 \%$ significance level; With top management shareholding is related, but the correlation didn't pass the significance level inspection; Positively related to the external independent directors proportion, but the correlation is not significant; With business relevance and negatively correlated with lineage group size。
\end{abstract}

\section{The problem is put forward}

Theory research shows that, due to the organization carrier of internal capital markets (such as $\mathrm{M}$ type enterprise and $\mathrm{H}$ holding company) the complexity of structure and internal capital allocation of confidentiality, and internal capital allocation with multi-level and multiple main body of the agency problem, corporate governance of internal capital markets is particularly complicated. Inside and outside corporate governance mechanism is imperfect, weak investor protection system of the environment, the internal capital market is likely to be alienated to the indemnification, likely to be damaging to the group members, the value of the enterprise value and the interests of the various related investment entities. From the practice of Chinese enterprise group internal capital, equity concentration and big shareholder control become a universal phenomenon in the listed company in China. Most of China's listed companies in the group control of internal capital market environment, then, how Chinese business group internal capital market efficiency? On the influence of the group's overall value? The main factors that influence the enterprise group's internal capital allocation has? In view of this, this article takes our country capital market of internal capital market is a group enterprise group as the research object, build multivariate regression model, try to solve the above three key problems。

\section{Sample and data sources}

Since 1999, in the Chinese capital market, appear the phenomenon of more than one control [1], that is, a final controller to control the phenomenon of many listed companies. And, and people are used to the many listed companies belonging to the same ultimate controller control referred to as the "system". In many listed companies in the composition of the "system" within a wide range of internal capital market, and publicly available data of listed companies, so this is a family group for us to study the internal capital market in the capital allocation behavior provides a good analysis of samples. This article select 2014 a-share non-financial listed companies in Shanghai and shenzhen two city as the research sample. Reference Claessens et al. (2000) [2] research methods, according to the equity of the listed company control chain information, for all the major shareholders of listed companies, the controlling shareholder or actual controller to carry on the back, if the major shareholders of listed companies, the controlling shareholder or its actual controllers can be traced back to the same economic subject, then these listed companies is defined as a family group. Lineage group still exist in the private company, but due to the data of a private company usually can't from public access to, at the same time, relative to the non-listed companies, the operation of China's listed companies within the group has obvious advantage in the position, and, by 
convention, the study of enterprise group usually listed companies within the group as the research object (Khanna, 2000) [3]. In this article, therefore, is a family group of listed companies as the research object

\section{The measure of the internal capital market value creation 。}

As for the measurement of enterprise value, empirical studies in the west are generally adopt tobin value. A few domestic studies with a price-to-book said enterprise value. These two indexes related to market value, however, due to the incompleteness of emerging market in China, the listed company stock price often far from its actual value, the value of tobin and city net can well reflect the enterprise value. Moreover, research on diversified enterprise value cannot simply be diversification and specialization enterprise value in direct contrast, enterprise need to measure relative to a single division, the relative value of the enterprise, namely the excess value. The advantage of relative value increase method is: can effectively measure the enterprise, the relationship between capital investment and capital appreciation is intuitively the enterprise capital appreciation and assets measurement and analysis on the usage, the internal capital market value creation, data accessible, easy to observe the test results, a simple and intuitive. Therefore, we adopt Rajan et al. (2000) [4] the research method of the calculation formula is:

$$
E V=\frac{M V_{d}}{R V A_{d}}-\sum_{j=1}^{n} \frac{B A_{j}}{B A_{d}}
$$

(1), is a diversified enterprise at the end of the market value of assets, this paper use is the sum of the assets at the end of the market value of listed companies; Enterprise is the replacement value of assets, this paper use is the sum of the at the end of the book value of assets of listed companies; Is the same as the diversified enterprise division has three independent business standard industry code of the weighted average tobin (at the end of the asset as weight); To the book value of assets 。

Calculating process of the calculation results show that (omitted), 102 is a group of 296 listed companies, mainly distributed in the manufacturing sector, accounting for 174 (58.78\%), mainly because our country enterprise group mainly based on state-owned manufacturing enterprises. Value as a whole, the results showed that the lineage excess value generally low, $53.4 \%$ of the lineage of the negative, that our company group's internal capital allocation inefficiencies 。

\section{An empirical analysis of the internal capital market allocation efficiency factors}

\section{1 research hypothesis}

In equity concentration and big shareholder control of Chinese listed companies, the agency problem on the level of ownership, the conflict of interest between large shareholders and minority shareholders in more prominent [5-8]. This article will control shareholders and the degree of difference of cash flow as a measure agency large shareholders and minority shareholders. Degree of control and cash flow rights differences = shareholders control - cash flow rights. The smaller the difference degree, said big shareholders more closely associated with the company's actual interests, major shareholders through internal capital markets occupy the smaller the possibility of a company, or vice versa. When the internal capital market is become a big shareholder interests transmission channels, internal capital market allocation efficiency must be low. Therefore, this paper puts forward the following hypothesis:

H1: control and the degree of difference of cash flow right is inversely proportional with the internal capital market efficiency, and is inversely proportional to the group enterprise value. H2: management ownership is lower, the internal capital allocation decisions easier to deviate from the group enterprise value maximization goal. H3: the proportion of the first big shareholder holds, the independent directors proportion is proportional to the efficiency of internal capital allocation, which is proportional to the group enterprise value. H4: the number of member companies and lineage group size lead to inefficient internal capital markets 。 


\section{2 research model and variable definition}

In a sample of this part used the lineage group in 2014 as the annual and stand in the perspective of ultimate control person, the lineage group as a whole, the analysis of the lineage of the influence factors of internal capital allocation excess value. The research model is as follows:

$$
E V=\alpha+\beta_{1} \text { Sep }+\beta_{2} \text { First }+\beta_{3} \text { Mshare }+\beta_{4} E+\beta_{5} \text { Num }+\beta_{6} \text { Size }+\varepsilon
$$

In type (1), is the excess value of lineage members is the ultimate control of the listed corporate control and cash flow right of difference degree, is the ultimate control of the listed members of enterprise ownership, for members of the public ownership enterprise management, is in proportion to the number of independent directors of the board of directors, is the number of a family member enterprise, is the size of control variables, the sum of enterprise assets is the lineage members. In view of this article is to stand in the Angle of the ultimate control person to study the influence factors of excess value, the family members and each lineage has 2 or more enterprises, the author of the data of listed companies to do the following treatment: the, and according to the department of the total share capital of listed companies as a weighted average of the process to get the corresponding values of the lineage; Is the listed company (for the independent directors proportion in the sum of the sum of the number of independent directors divided by the number of board members of the enterprise. Variable definitions are shown in table 1 。

Table 1, variable definition and description

\begin{tabular}{|c|c|c|}
\hline Variable names & abbreviations & variable description \\
\hline The excess value & $E V$ & $\begin{array}{l}\text { Excess value of lineage, } \\
\text { lineage ultimate control of } \\
\text { the final control and the } \\
\text { difference between the } \\
\text { cash flow right }\end{array}$ \\
\hline $\begin{array}{l}\text { Control and the degree of } \\
\text { the separation of cash flow } \\
\text { right }\end{array}$ & Sep & $\begin{array}{l}\text { the value is, that the } \\
\text { degree of separation, the } \\
\text { greater the indicates }\end{array}$ \\
\hline $\begin{array}{l}\text { The first big shareholder } \\
\text { shareholding }\end{array}$ & First & $\begin{array}{l}\text { the greater the ultimate } \\
\text { control person } \\
\text { shareholding lineage }\end{array}$ \\
\hline Executives shareholding & Mshare & lineage ownership \\
\hline $\begin{array}{l}\text { The independent directors } \\
\text { proportion }\end{array}$ & E & $\begin{array}{l}\text { senior management } \\
\text { personnel is a family of } \\
\text { independent director } \\
\text { number accounts for the } \\
\text { proportion of the board of } \\
\text { directors }\end{array}$ \\
\hline Degree of diversification & Num & $\begin{array}{l}\text { is a member of the family } \\
\text { enterprise number }\end{array}$ \\
\hline Enterprise scale & Size & $\begin{array}{l}\text { the end is the natural } \\
\text { logarithm of the book } \\
\text { value of the total assets of } \\
\text { the family }\end{array}$ \\
\hline
\end{tabular}

\section{3 descriptive statistics}

Descriptive statistics results show that each department (excess value) of the mean is 0.049, the standard deviation is 0.765 , that is group internal capital allocation value creation is negative, the family as a whole, is a family of internal capital allocation is invalid; According to total equity as a weighted average of the processing degree of the lineage of ultimate control right of two gap is larger, the higher percentage of the first largest shareholder, shows that China's lineage group 
ownership concentration and two rights separation degree is big, big shareholders the phenomenon of excess control; Executives shareholding smaller, suggesting that the management equity incentive has not been widely used in the lineage group; Lineage members of the group companies an average of 2.88, and total assets scale, shows that our country is larger ethnic group 。

4.4 the results of the regression analysis

The empirical results are shown in table 2. (1) from the multiple regression results, the excess value of group, the ratio is related with the first big shareholder holds, separation and cash flow rights and control difference degree negative correlation, and by $5 \%$ significance level, which suggests that, on the one hand, is a family of ultimate controller in the listed company ownership rights ratio increases, by increasing the group's overall capital allocation efficiency is to increase the group's overall value, so as to maximize their own interests; Separation and cash flow rights, on the other hand, when the control difference degree increases, the ultimate controlling shareholder control may be out of selfish motives, use of internal capital markets deprive the interests of minority shareholders, at this point, the company group, the internal capital allocation is a place for the indemnification. (2) group and top management shareholding excess value positive correlation, but the correlation didn't pass the significance level, the main reason is that lineage group management agency problem is not the main, this is in internal capital market the main agency problem to size the facts of the conflict of interest between shareholders. In our lineage group listed company executives shareholding is generally low, zero stake is serious, lead to top managers in the role of internal capital market capital allocation activities are limited. This shows the current limitation of lineage group executive compensation incentive in our country, and long-term equity incentive mechanism has not really established. This with maike (2011) [9] basic similar results. (3) corporate excess value and the external independent director proportion, but not dramatically. This suggests that belong to the board of directors of the listed company role without effective play, governance effect is not obvious. The independent director system is in reference to the western experience in China, and establish a system to protect minority shareholders interests are not violated. Practice has proved, however, the independent director in the maintenance of small and medium shareholders' interests and no effective play a good role, as a result of the independent director is mainly decided by the controlling shareholder and its compensation has the factors of the listed company to pay, the independent director system has yet to play their role in corporate governance. (4) corporate excess value with the number of listed companies and is negatively correlated with group size, which suggests that the family of homologous group, the more the number of listed companies, total assets, the greater the lineage group, the lower the overall value. To this, this paper argues that the greater the number of member enterprises, total assets (that is, the diversification degree), the greater the answer to the shareholders for the space of internal capital markets, the greater the managers "rent-seeking" space is, the greater the lower the efficiency of internal capital market, the greater the enterprise value. This with JiHao (2011) [10] one of the central enterprises listed companies scale and efficiency of internal capital market exists negative correlation research conclusions are basically identical 。 
Table 2, the return of internal capital market allocation efficiency factors

\begin{tabular}{|c|c|c|}
\hline Variable & $\begin{array}{c}\text { expected } \\
\text { symbol }\end{array}$ & $\begin{array}{l}\text { regression } \\
\text { results }\end{array}$ \\
\hline \multirow{2}{*}{ Const an $t$} & \multirow{4}{*}{-} & $0.078^{* *}$ \\
\hline & & (1.120) \\
\hline \multirow{2}{*}{ Sep } & & $-0.322^{* *}$ \\
\hline & & $(3.420)$ \\
\hline \multirow{2}{*}{ First } & \multirow{2}{*}{+} & $0.013^{* *}$ \\
\hline & & (1.845) \\
\hline \multirow[b]{2}{*}{$E$} & \multirow{2}{*}{+} & 0.045 \\
\hline & & (1.587) \\
\hline \multirow{2}{*}{ Num } & \multirow{2}{*}{+} & 0.301 \\
\hline & & (1.745) \\
\hline \multirow{2}{*}{ Num } & \multirow{2}{*}{-} & -0.002 \\
\hline & & $(0.655)$ \\
\hline \multirow{2}{*}{ Size } & \multirow{2}{*}{-} & -0.022 \\
\hline & & $(-0.801)$ \\
\hline $\operatorname{Adj} R^{2}$ & & \\
\hline$F$ & & \\
\hline
\end{tabular}

- *, *, respectively $5 \%$ and $10 \%$ confidence level

\section{The main research conclusion}

This article is a family enterprise group in China as the research object, examine enterprise group's internal capital market value creation and its influencing factors, and draws the following conclusions: (1) the value of our country enterprise group, is a family enterprise) to create a generally low. In this paper, the research shows that our country is a family enterprise group, 53.4\% of the lineage of the excess value is negative, that our country enterprise group's internal capital allocation inefficiencies. (2) is a family enterprise in China's internal capital market value creation mainly affected by all layers of the problem of agency, agency and management correlation is not big. Is mainly controlled by the shareholders' equity ratio and characteristics. In this paper, the empirical analysis shows that, the excess value of group, the ratio is related with the first big shareholder holds, separation and cash flow rights and control difference degree negative correlation, and by 5\% significance level, inspection; With top management shareholding is related, but the correlation didn't pass the significance level inspection; Positively related to the external independent directors proportion, but the correlation is not significant; With business relevance and negatively correlated with lineage group size。

\section{References}

[1] Claessens S.,Simeon Djankov,J.H.P.Fan,Larry H.P.Lang. Disentangling the Incentive and Entrenchment Effects of Large Shareholdings[J].Journal of Finance,2002,57(6):2741-2771.

[2] Wolfenzon,D.A Theory of Pyramidal Ownership[J].Unpublished Working Paper.Harvard University,Cambridge,MA,1999:25-55. 
[3] Alchian,Armen A.Corporate management and property rights.In:Henry Manne,eds.Eonomics Policy and the Regulation of Corporate Securities[M].Washington,DC:American Enterprise Institute,1969.63-65

[4] Williamson,O.E.Markets and hierarchies:Analysis and antitrust implications[M].New York:The Free Press.1975

[5] Gertner,R.,Scharfstein,D.,Stein. Internal versus external capital markets[J].Quarterly Journal of Economics,1994,109(4):1211-1230

[6] Stein,J.Internal capital markets and the competition for corporate resources[J].Journal of Finance, 1997,52(1):111-133 